\title{
Introduction to the Special Issue: \\ Globalization as a Challenge for Business Responsibilities
}

\author{
Andreas Georg Scherer, Guido Palazzo, and Dirk Matten ${ }^{1}$
}

unedited version as of May 14, 2009

for correct quotations see the original publication in

Business Ethics Quarterly Vol. 19 (2009) No. 3: 327-347 (forthcoming July 2009)

Abstract: This paper assesses some of the implications of globalization for the scholarly debate on business ethics, CSR and related concepts. The argument is based, among other things, on the declining capacity of nation state institutions to regulate socially desirable corporate behavior as well as the growing corporate exposure to heterogeneous social, cultural and political values in societies globally. It is argued that these changes are shifting the corporate role towards a sphere of societal governance hitherto dominated by traditional political actors. This leads to a discussion of the ambivalent results of such a process for a responsible corporate role in a globalized world. While assessing the current reception these changes have received in the management literature, the contribution of the four papers of this Special Issues are framed and evaluated. The argument closes by highlighting avenues of future research on this new challenge.

\footnotetext{
${ }^{1}$ Prof. Dr. Andreas Georg Scherer (University of Zurich, andreas.scherer@iou.uzh.ch); Prof. Dr. Guido Palazzo (University of Lausanne, guido.palazzo@unil.ch); Prof. Dr. Dirk Matten (York University, DMatten@schulich.yorku.ca)
} 


\section{Introduction: Globalization as a Challenge for Business Responsibilities}

Globalization can be understood as the intensification of social interrelations among distant locations (Beck 2000; Giddens 1990). This process is initiated by political decisions such as the reduction of tariffs and non-tariff barriers to the exchange of goods, technology, capital, services, and labor, and the opening of markets through liberalization and deregulation policies. It is further accelerated by political upheavals (e.g. the fall of the iron curtain) and by technological advancements in communication, media, and transport, and is accompanied by socio-cultural processes such as increasing cross-border migration, the erosion of traditions, growing individualization, and the emergence of pluralist societies with heterogeneous values, cultures and life-styles (Cohen and Kennedy 2000). As a result national borders and geographic distances are losing their economic and political significance (Scholte 2005). The regulatory power of nation state governance is fading, and received values and traditions are eroding (Habermas 2001). As a consequence global business firms operate in a complex and uncertain environment with gaps in regulation and ill-defined rules of appropriate business conduct (Scherer and Palazzo 2008a).

The globalization of society erodes established ideas about the division of labor between the political and economic spheres, and calls for a fresh view concerning the role of business in society. Some transnational corporations (TNCs) have started to change their role from one of simply following the rules to one of creating the rules of the economic game. They already assume social and political responsibilities that once were regarded as belonging to government (Matten and Crane 2005; Scherer at al. 2006). They engage in the production of public goods (e.g., public health, education, social security) (Kaul et al. 2003), and in selfregulation to fill global gaps in legal regulation (Cragg 2005; Scherer and Smid 2000) and to promote societal peace and stability (Fort and Schipani 2004). Some corporations do not simply comply with societal standards in legal and moral terms; they engage in political processes that aim at setting or redefining those standards in a changing, globalizing world 
(Scherer and Palazzo 2007). Those activities go beyond the received understanding of stakeholder responsibility and corporate social responsibility (CSR) as it was conceptualized in the past decades (that is, as the corporations' adaptation to societal expectations; Carroll 1979; Strand 1983). TNCs operate in a complex environment with heterogeneous, often contradictory legal and societal demands. As a consequence the simple adaptation to a particular set of social demands will not create social acceptance but will instead lead to a mismatch with other societal expectations and the rise of legitimacy questions (Palazzo and Scherer 2006).

The social activities of business firms, however, often go beyond the traditional conception of politics as power politics, as it is commonly understood in the management literature. There it is assumed that politics is a process of furthering one's interests by imposing one's will on others (e.g. Baron 2003) and that business firms engage in public policy only for profit oriented reasons, that is, in order to influence the political system so that the interests of private businesses are served and their profit seeking ambitions are not restricted by strong regulations (Bonardi et al. 2005; Hillman et al. 2004). Seen from this viewpoint, politics is conceptualized as a power game within a complex system of checks and balances and the outcomes of the political process are explained with the help of power differences among actors with irreconcilably opposed private interests (Elster 1986). However, it remains an empirical question whether all of the corporate social and political activities described above can be explained by rational profit seeking behavior, or whether other factors such as altruism, prosocial behavior, isomorphic adaptation to the changing institutional context, pathdependencies, or argumentative entrapment (i.e., the need "to walk the talk") play a significant role in the political behavior of business firms.

At the same time, it is obvious that the political engagements of business firms do not necessarily contribute to the common good and thus are not always socially acceptable (Banerjee 2007, Reich 2007). Therefore, questions remain as to when political strategies of business firms should be considered legitimate versus when they should be considered dan- 
gerous to society and democracy. It addition, it appears that the traditional concepts of corporate politics as power politics have emphasized outcomes and uneven power structures, but generally have neglected the communicative conditions of the political process in which people try to interpret issues of common concern, attempt to regulate some aspects of their social and economic interactions, or try to define a common direction for their course of action (Young 2004). Business firms are both subject and object of this communicative political process of regulating the economy, but this political role for businesses has not yet been sufficiently explored.

The aim of this special issue therefore is to discuss the consequences of the social and political mandate of the corporation, and to examine the implications for theory and practice of businesses operating in a globalized world. In our call for papers we asked for contributions from the social sciences, humanities, and professional fields that go beyond established ideas on the role of business in a global society. We invited both theoretical and empirical contributions from different schools of thought, and particularly welcomed papers that argue across various levels of analysis (e.g. global level, national level, firm level, individual level) or that connect the potentially relevant disciplines (management studies, sociology, international law, political theory and philosophy, etc.). By the end of the deadline we received 31 paper submissions. 16 papers were eligible for review process and finally five papers have been accepted after two or three revisions. In the present special issue of Business Ethics Quarterly four papers are published; one paper that was originally submitted for the special issue has already been published in a previous issue of Business Ethics Quarterly (Hsieh's article in number 2, volume 19, April 2009).

This introduction is structured as follows. In the following section we briefly describe the limitations of traditional views of the political role of global business. In order to demonstrate the practical significance and theoretical challenge of this issue, we refer to both the desirable and the problematic consequences of corporate political engagement on the global 
playing field. We briefly summarize the four articles in this special issue. In the concluding section we explain why we need a new conception of the political role of business, and point to some of the challenges that need to be explored in future research.

\section{Corporations as Political Actors? -}

\section{The Limitations of Current Theories on the Political Responsibility of Business}

So what exactly do we mean if we speak of corporations as political actors? The main feature of the political nature of the corporations is that they increasingly actively participate in societal governance, and that they take part in the authoritative allocation of values and resources. (see also Crane et al. 2008: 1). This, however, is a contested idea which causes resistance from various schools of thought. Many economists argue that corporations are institutions which are designed to make profits (Sundaram and Inkpen 2004). They reject any social or environmental engagement of business firms that goes beyond legal requirements and does not contribute to profit making (Friedman 1970; Hendersen 2001). However, the economist's argument aims not only to protect the property rights of owners of firms and serve the interests of the shareholders. Rather, economists maintain that private profit seeking contributes to the wellbeing of society via the allocation function of the market system (Jensen 2002). In addition, economists emphasize that managers of business firms are neither elected nor controlled democratically. Therefore, any socio-political engagement by managers not only violates the legitimate claims of shareholders, but is a danger for democratic society (Friedman 1962, 1970; Baumol and Blackman 1991).

Many globalization critics, such as civil society movements, human rights advocates, and environmental protection groups, argue that social or environmental projects of business firms are nothing more than "window dressing" or "green washing" (Klein 2000; Laufer 2003), as corporations attempt to create positive public images without necessarily modifying their problematic business activities: "In this form, corporate social responsibility is cheap and 
easy." (Roberts 2003: 250) These critics conclude that business firms engage in these CSR projects either to enhance their reputation or for financial reasons (by managing their risks or taking a chance to earn extra money by investing in such projects). Business firms, they assume, have no intrinsic motivation to contribute to the common good; rather they are only concerned with making profit. Therefore, many globalization critics argue that the political activities of corporations are a potential danger for society, as they are not intended to serve the public good but the egoistic motives of managers or firm owners, often at the cost of their social or ecological environment (Korten 2001). These negative externalities may occur in particular where transnational firms operate in failed states with weak or even absent regulation and enforcement mechanism. Therefore transnational corporations have been accused especially since the $1970 \mathrm{~s}$ - of being an expression of an imperialist capitalist system and of exploiting developing countries at the expense of the wellbeing of their citizens (Brewer 1980; Mandel 1999; Warren 1980). Today, TNCs have become even more powerful in influencing and determining the political, social, and economic conditions in their host countries; they have become the true "leviathans" of our time (Chandler and Mazlish 2005).

At the same time, the social political engagement of corporations has become a widespread phenomenon: "That corporations do sometimes act as social change agents is not in dispute; indeed it is an empirical reality around the world. Moreover it is becoming a political reality as well." (Bies et al. 2007: 788) Despite the critical comments from various perspectives, a growing number of business leaders seem to assume responsibilities that go beyond profit seeking and compliance to the legal minimum. Without doubt, some of these corporate initiatives may be part of public relations strategies and serve the purpose of creating a positive corporate image while leaving the essential value chain and business processes untouched (Banerjee 2007; Roberts 2003). Moreover, in many instances corporations assume this political role without even being aware of it, let alone intending to do so. Good examples are companies that have taken over public services from government in healthcare, education or pub- 
lic transport (Crane and Matten 2005). In some cases it can even be assumed that the internalization of social and environmental responsibilities not only changes a business's operations themselves, but can even lead to a transformation of the business's perception of its role in society (Zadek 2004).

We suggest that current theorizing on the political responsibilities of business firms does not sufficiently take account of these changes, as it is mainly based on (1) an economic view of the role of the business firm and (2) a strict separation of public and economic domains: "companies work to maximize their strategic freedom within the bounds set by government. ... The role of the firm is separate from that of government ..." (Detomasi 2008: 812-13) Seen from this perspective, business firms are only considered to be private actors, focusing on their economic interest in earning profits while complying with the legal rules provided by governmental regulation and the moral rules of their social environment. This perception of corporate responsibility is based on the premise that markets and market actors are sufficiently controlled and controllable by governments (Sundaram and Inkpen 2004). In fact, in economics, finance and other business-related disciplines the assumption is widely shared that governments are powerful and even regulate too much and should rather decrease the level of control (Norberg 2003). It is commonly thought that taking care of issues of public concern is the exclusive responsibility of the state, and any policy of a business firm is considered an expression of its profit-seeking strategic attitude. Ironically, both of these assumptions are shared by many defenders of free trade and TNCs and by globalization critics.

In management studies the political activities of business firms have been widely discussed (see, e.g., Boddewyn and Brewer 1994; Hillman et al. 2004; Schuler and Rehbein 1995; Shaffer 1995). The established view on the political behavior of business firms is based on quite a distinct version of power politics that is underlying conceptions such as "political strategy" (Hillman et al. 2004), "political lobbying" (Shell 2004), or "private politics" (Baron 2003). This instrumental view on politics is also common in much of political science, 
whereby the so-called "real politics" or Realpolitik approach is one of the dominant paradigms (see, critically, Wayman and Diehl 1994). The political strategy approach has focused on the strategic behavior of corporations "to shape government policy in ways favorable to the firm" (Hillman et al. 2004: 838). It is based on the premise that "managers choose to engage in political activity to enhance the value of the firm" (Hillman et al. 2004: 839, emphasis in the original here omitted). Empirical research is dedicated to the question of what factors influence the success or failure of political strategies, i.e. of corporate lobbying. Some authors have even written manuals for corporate managers on how to influence the political system (e.g. Shell 2004).

Likewise, many students of corporate social responsibility favor an instrumental approach and search for a "business case of CSR" in order to show if and under what conditions CSR projects may contribute positively to financial performance (see, e.g., Aupperle et al. 1985; Berman et al. 1999; for a critical review see Margolis and Walsh 2003). These studies are based on the premise that profit-making is the final goal of business and that any corporate policy and any corporate social or political engagement must be understood as an instrument to rationally achieve this goal.

These schools of thought work within the assumption that the business of business is business (Friedman 1962, 1970), while it is the task of the state to serve public interest (Frederick 1998; Detomasi 2008; Sundaram and Inkpen 2004). The state defines the rules of the game in processes of public deliberation that regulate private businesses in otherwise free markets (see, e.g., Colley et al. 2003: 7). Private businesses are forced to comply with these regulations by means of legal and administrative sanctions, so that the consequences of market exchanges contribute to the public good and externalities are avoided, or at least compensated. Other than that, private businesses have no additional social or political responsibilities; rather their only responsibility is to earn profits (Friedman 1970). In their comprehensive review of the management literature, Walsh, Weber, and Margolis (2003: 865) have character- 
ized this dominant view and its assumption that the state is the only significant actor in public policy: "Property rights, the invisible hand of the market, and the government are entrusted to solve society's problems. Corporate managements are to play no direct role in ensuring the social welfare of society".

However, as argued above, these proposals work on the premise that the state-system is able and sufficient, via regulation and enforcement, to direct the results of the strategies and actions of self-interested economic actors toward societal good. As a consequence, the economic theory of the firm has focused on economic responsibilities only, and delegates the resolution of societal issues to institutions and actors outside the market system (Sundaram and Inkpen 2004).

We hold that during the process of globalization both of these assumptions - about the sustained capability and efficiency of the nation state system on the one hand, and the separation of public policy and private business on the other - need to be reconsidered (see, Beck 2000; Cragg 2005; Kobrin 2001; Scherer and Palazzo 2008b). Today, businesses do not necessarily operate within the borders of a clearly defined legal system and a more or less homogeneous set of social expectations. Instead many operations are shifted offshore and beyond the reach of the rule of law or the enforcement of taxes or regulations (Palan 2003). In addition, nation state institutions face social and environmental challenges that have transnational origins and cannot be regulated or compensated unilaterally by national governance. This regulatory gap is only partly compensated by new global governance mechanisms to which civil society and private actors, along with governments, contribute knowledge and resources. Unlike nation state governance, these new governance mechanisms consist of nonhierarchical networks of private and public actors, rely on voluntary action, and have only weak enforcement measures (Braithwaite and Drahos 2000).

These developments have at least two consequences: First, the nation state is losing part of its regulatory power, although it remains a significant actor in emerging global gov- 
ernance. Second, the private-public distinction gets blurred. Business firms - for better or worse - engage in public policy (Scherer et al. 2006). Some corporations act as "corporate citizens" and get actively involved in the governance of human rights, public corruption, social and environmental standards, and thus directly shape the public good (again, for better or for worse) where the state is unable or unwilling to do so (Matten and Crane 2005). Other business firms, however, take advantage of the lack of regulation and enforcement and aggressively foster their economic interests, often at the expense of the surrounding communities and the natural environment (Banerjee 2007).

\section{Dark Sides and Bright Sides of Global Business: \\ Corporate Behavior on the Global Playing Field}

The idea of viewing the corporation not only as an economic but also as a political actor thus builds on two seemingly contradictory observations (Palazzo and Scherer 2008). On one hand, the global regulatory gap seems to trigger deviant corporate behavior (Gond et al. 2009). Some multinationals are accused of abusing that gap and (directly or indirectly) violating human rights in their globally expanded operations, especially in those areas where state institutions, legal restrictions, and enforcement are weak or almost non-existent (e.g., Mokhiber and Weissman 1999; Korten 2001). On the other hand, corporations get involved in self-regulatory activities (Scherer and Smid 2000) and engage in the production of public goods beyond their immediate business context (Kaul et al. 2003; Valente and Crane 2009). We label these two observations the dark and the bright side of global business.

The dark side: It has been argued that weak global governance mechanisms have led to a return of the robber baron phenomenon (Rawlinson 2002). The term "robber baron" symbolizes the dark side of unchecked capitalism. It has been used to characterize the industry leaders of 19th century frontier America, the Vanderbilts, Rockefellers, Morgans and Carnegies. These captains of industry made a clear distinction between how to make and how to use 
a profit. Still under the influence of a Puritan work ethics, they interpreted worldly success as a sign of divine grace and felt a duty of "giving back to society". They gave huge amounts of money to charities or even used their fortune to establish foundations. As Rockefeller once stated, "I believe it is my duty to make money and still more money and to use the money I make for the good of my fellow man according to the dictates of my conscience" (see Norton et al. 1986: 490). Thus, the fact that CSR is often considered merely to be a philanthropic issue (see, e.g., Porter and Kramer 2002) might partly result from the ideological roots of $19^{\text {th }}$ century capitalism.

At the same time, however, these capitalists became notorious for their aggressive drive to increase their wealth at almost any cost, thus demonstrating that ethical duties might be linked to using their profit but certainly not to the process of making it. Vanderbilt's notorious words "What do I care about the law? Haven't I got the power?" (see Josephson 1934: 72) illustrate the libertarian ideology of the robber barons whose workers died in mines, oil fields, factories, or railroad projects. Child labor was a common phenomenon at that time and grew at a high pace. It tripled between 1870 and 1900, and in 1900 almost $13 \%$ of all textile workers were younger than sixteen (Norton et al. 1986) working under miserable conditions in so-called sweatshops. Even social Darwinist, survival of the fittest thinking found fertile soil in laissez faire, gilded age society (Destler 1946). Robber baronism therefore found its optimal conditions in the transition from rural economy to industrial economy of the $19^{\text {th }}$ century United States (Perrow 2002).

We suggest that the ongoing process of globalization creates a comparable context of transition from domestic economies to a global economy with weak governance mechanisms. Some multinational corporations are criticized for abusing the regulatory vacuum, thereby displaying a behavior that is comparable to that of the notorious robber barons (Mokhiber and Weissman 1999; Korten 2001). Corporations have been accused of profiting from the legal vacuum in African civil wars (Dunfee and Fort 2003; Guidolin and LaFerrara 2007, Roberts, 
2003), for collaborating with the military forces of corrupt political regimes in Nigeria, Indonesia and elsewhere (Clapham 2006; Taylor 2004), for bad working conditions in their supply chains, including child labor and slave labor (see, e.g., Bales 1999, 2005; Hightower 2002). Comparable issues are, however, not only a problem in developing countries, but can also be observed in the industrialized countries (see Banerjee 2003 for Australia; Saviano 2008 for Italy). As a consequence of these developments, some multinational companies have been described as the symbol of "what is wrong with twenty-first century capitalism" (Beaver 2005: 159).

While the robber baronism of the $19^{\text {th }}$ century was sanctioned by Darwinistic ideology, that was a common view at that time, today the free trade mantra of some voices in economic theory (e.g., Irwin 2002; Krauss 1997; Norberg 2003) seem to deliver a comparable legitimization for arguably deviant corporate behavior. Krauss (1997: 51) has, for instance, argued that "the way to help poor people abroad is to open our markets to them not to force them to adopt ... human rights standards," and claims that workers in the developing countries have voluntarily agreed to the terms of their contracts and thus have accepted the prevailing labor conditions even though they may be unsafe and unhealthy. Martinez-Mont (1996) has provocatively argued that it is better to have a lousy job than no job at all. The implicit assumptions in these positions is that prospering markets drive the overall development of poor societies and lift them to a higher level, with a stronger regulatory framework for the protection of human rights and democracy as a consequence. As long as these rights are taken as the precondition, the development process is slowed down (Barro 1994).

The Bright Side: However, the intensifying critique by civil society actors - who make doubtful business practices of multinational corporations transparent (den Hond and de Bakker 2007) - and the recent use of the US Alien Tort Claim Act and other laws to sue corporations for human rights violations in US courts (Clapham 2006), has convinced some companies to change business practices, to expose their activities to emerging soft law regulations, 
and even to participate in global governance initiatives and to engage with CSR projects for the common good. Up until now more than 4700 business firms have subscribed to the United Nations Global Compact, and have publicly committed to voluntarily support human rights, to enforce social and environmental standards, and to fight corruption in their entire sphere of influence (see www.globalcompact.org, accessed May 1, 2009). These corporations assume responsibilities that once were considered the mandate of the state only. They cooperate in private-public-partnerships with civil society actors, international organizations and state agencies in the resolution of social and environmental problems and in the production of public goods (Reinicke and Deng 2000).

It seems that globalization is propelling a new distribution of power among national governments, economic actors, and civil society (Mathews 1997; Wolf 2008). The limited influence of national governments on large corporations is - at least partly - balanced by the politicization of civil society. What has been labeled "globalization from below" (Beck 2000: 68) describes the growing power of civil society actors to influence decision-making processes in governments and corporations. "NGO's role and influence have exploded" (Mathews 1997: 53). With the Internet forcing an ever-growing transparency of corporate behavior, an increasing number of these civil society activities are directed at corporations (Dryzek 1999: 44; Klein et al. 2004) whose business practices are scrutinized carefully (Spar and La Mure 2003), and who are confronted with growing demands (Walsh et al. 2003) and changing conditions of legitimacy (Palazzo and Scherer 2006).

Under the pressure of changing societal expectations, some global corporations have started to intensify their CSR engagement. As described in the introduction, many corporate initiatives intrude into domains that traditionally belonged to the sphere of political responsibilities of state actors (Valente and Crane 2009; Walsh et al. 2003). Business firms sometimes unilaterally address issues of public concern, such as Novartis' engagement in public health (Leisinger 2009), Coca Cola's fight against AIDS (Asongu 2007; Okie 2006), or Chiquita's 
initiatives to enhance social and labor rights in the banana industry (Were 2003). Aside from these firm level initiatives (for overviews see Hess et al. 2002; Hill et al. 2003) many companies engage in industry level or policy specific multilateral self-regulation initiatives (Gilbert and Rasche 2007) that aim to standardize, enforce and control business practices at the industry or global level, either in particular policy areas such as (for example) human rights, money laundering, corruption, or deforestation, or in certain industries (e.g. banking, retail, food, apparel, consumer goods, etc.). Some of the numerous examples are the Forest Stewardship Council for the protection of the world's forests (see www.fsc.org), the Equator Principles to support sustainable money lending in the banking industry, the Wolfsberg Principles to fight money laundering and corruption (www.wolfsberg-principles.com), the Global Reporting Initiative on the standardization of social and environmental reporting (www.globalreporting.org), the Social Accountability 8000 certification initiative to monitor supply chains in the consumer goods industries (www.sa-intl.org), the Business Leaders Initiative on Human Rights to support human rights (www.blihr.org), or the Kimberley Process, a joint initiative of governments, business firms and civil society to ensure that the diamond industry does not support violence (www.kimberleyprocess.com). These kinds of initiatives are mushrooming, and they represent a new form of global governance that - unlike national governance - includes non-state actors such as corporations and NGOs, consists of nonhierarchical networks, and relies on voluntary action and weak enforcement mechanisms (Bernstein and Cashore 2007).

These political initiatives and processes go beyond the mainstream CSR discussion, which assumes an intact division of labor between state actors and economic actors (Scherer and Palazzo 2007). While the traditional understanding of CSR still builds upon the isomorphic approach that demands compliance with society's moral and legal standards (see, e.g., Strand 1983; Swanson 1999), some corporations have started to set or redefine those standards, thereby assuming a politically enlarged responsibility (Scherer et al. 2006). 
Discussing the cultural and institutional consequences of globalization for governmental, business and civil society actors, researchers have begun to redefine the role of the nonstate actors in the process of global governance. These discussions and approaches are significant for the future theory development in corporate social responsibility and business ethics, since they offer concepts that include, explain and examine the described phenomena of private political activities. The present special issue contributes to this discussion.

\section{New Avenues for Research: The Contributions to the Special Issue}

The four papers that are included in the special issue cover various levels of analysis (e.g., global level, organizational level) and policy issues (e.g., human rights, security). They are good examples of the new research on the role of business in a global society. ${ }^{2}$

Stephen Kobrin, in "Private Political Authority and Public Responsibility: Transnational Politics, Transnational Firms and Human Rights," explores the question of whether transnational corporations should be held directly responsible for human rights violations. He argues affirmatively and explores various options on how TNCs can be held responsible. He suggests that the global political economy is currently in a transition from the Westphalian to the Post-Westphalian world order, with an increasing ambiguity of borders and jurisdictions, a fragmentation of authority, and a blurring of the separation between private and public spheres. TNCs have become powerful actors that assume authority in the international political system. They supply public goods, set social and environmental standards, and participate in political negotiations. Kobrin concludes that "political authority should imply public responsibility". When it comes to the question of how TNCs can be held accountable, Kobrin emphasizes four criteria: (1) the mechanisms have to be consistent with the Post-Westphalian system, (2) they cannot be based only on voluntary compliance, (3) they must be considered

\footnotetext{
${ }^{2}$ The paper by Hsieh (2009) was originally accepted for the special issue but was included in Business Ethics Quarterly No. 2/2009.
} 
both authoritative and legitimate, and (4) the scope of their coverage must be limited to a universally accepted set of human rights. Kobrin distinguishes various mechanisms within a $2 \times 2$ matrix, with a hard law/soft law dimension and an international (emphasis on state actors)/transnational (emphasis on state and non-state actors) dimension: 1) voluntary codes of conduct by either firms or international organizations, 2) international law that emphasizes the central role of nation states in international law, 3) a transnational solution, which he considers a hybrid form of hard-law and soft-law mechanisms. Kobrin analyses the potential and limitations of each of these mechanisms, and argues that a hybrid form - private-public actor collaborations with reliance on a mixture of hard and soft law - is most suitable for the current post-Westphalian order, although he hopes that the soft mechanisms may eventually emerge into harder forms of law.

Ingo Pies, Stefan Hielscher and Markus Beckmann, in "Moral Commitments and the Societal Role of Business: An Ordonomic Approach to Corporate Citizenship," contribute to the debate on the political role of the corporation on at least two levels. First, they provide a conceptual framework for systematically differentiating conventional CSR approaches from a politically informed view of 'corporate citizenship' (CC) as recently espoused by several authors (e.g. Norman and Néron 2008, Crane et al. 2008). Based on rational choice and game theory (the eco-'nomic'-part of their 'ordonomic' approach), they show that corporations become increasingly involved in societal governance, both by setting rules (e.g. by self regulation) and by initiating rule-finding discourses. Thus corporations assume responsibility for the institutional settings that govern and structure political processes in society (the 'ordo'-part of their 'ordonomic' approach). It is here where their paper sees the key difference between CSR and CC. Second, their conceptual framework addresses another controversy in the literature on $\mathrm{CC}$, namely the question of why self-interested and profit-seeking actors would possibly engage in these political activities (see, sceptically, e.g. van Oosterhout 2005, 2008). For Pies and co-authors this indeed can be the case, and based on a carefully crafted, economic frame- 
work they identify four specific situations wherein a company would see it in its utter selfinterest to engage in $\mathrm{CC}$ activities. For the readers of $B E Q$ the paper is a fascinating read for many reasons, two of which we would highlight here. To start with, there have not been too many papers in the business ethics literature recently that use economic methods in such a skillful and radical manner. Furthermore, in coining their 'ordonomics' term the authors engage in one of the favourite past-times of scholars, namely releasing new terminology into the academic community. While we believe that their approach may be considered controversial by some, we nevertheless think that in its current form it makes a rather original and valuable contribution to the debate.

In "Private Security Companies: Issues in Corporate and Stakeholder Responsibility," Heather Elms and Robert Phillips examine the legitimacy of the private security industry. Private security companies (PSC) play an important role in modern warfare and global security. They work for various customers such as governments, corporations and humanitarian organizations. The ongoing war in Iraq shows the growing relevance of private security companies, with the number of U.S. forces almost being matched by PSC employees. Building on Suchman's (1995) concept of organizational legitimacy, Elms and Phillips argue that the consumption of PSC services points to the existence of audience-specific pragmatic legitimacy (societal acceptability based on the perceived utility of PSC's activities). However, because of their growing power, the global expansion, and the widening regulatory gap in which PSC operate, these local pockets of pragmatic legitimacy become insufficient. The industry is confronted with a rising tide of critique from the mass media, lawmakers and various civil society actors, questioning the moral legitimacy of its customers, objectives and methods (societal acceptability based on the perceived normative appropriateness of PSC's activities). Building on discussions in neoinstitutional theory and stakeholder theory, Elms and Phillips discuss how PSC and their key stakeholders (customers, employees, financiers) can mutually reproduce the moral legitimacy of the industry. The authors discuss the reciprocal moral obligations of PSCs and customers (e.g. the 
legitimacy of objectives), employees (e.g. the professionalization of behavioral standards) and financiers (e.g. the appropriateness of information) that would build the foundation of morally legitimate PSC. The paper concludes with a discussion of four broad standards of responsibility that Elms and Phillips propose for the evaluation of the moral legitimacy of PSC: transparency, accountability, professionalism and dignity.

Stephanie Hiss, in "From Implicit to Explicit Corporate Social Responsibility: Institutional Change as a Fight for Myths," provides a rather fresh and unconventional view on the political dimensions of CSR. Her's is a case study on the proliferation and rise of CSR practices in Germany, a country whose legacy in this area is a relatively recent one and whose institutional framework governing economic activity differs strongly from the AngloAmerican approach. The paper contributes to our understanding of the political dimensions of CSR in a number of ways. First the paper shows how deeply embedded CSR practices are in the regulatory, political and customary institutions of a specific geographic context. Second the paper shows that change within these institutions is a political process in which corporations, next to governments and civil society actors, play an intricate, active and crucial role. Last, but by no means least, by using neo-institutional theory the paper not only showcases the value of interdisciplinary - in this case sociological - perspectives on questions of business ethics and responsibility. Hiss's theoretical lens also highlights the political dynamics among different societal actors in shaping the CSR activities of individual corporations.

\section{In Search of a New Conception of the Political Role of Business:}

\section{Challenges for Future Research}

In the past few years numerous academics have advocated a new conception of the political role of business in society. Dubbink (2004) called for a reinterpretation of the governmentbusiness-civil society-interaction. Walsh, Weber, and Margolis (2003) considered the analysis of this interaction to be one of the main challenges of CSR research and suggested to look 
beyond the established borders of management theory (Walsh 2005). And Barley (2007: 214) thinks we need to reverse the thinking "about how to study the relationship between organizations and their environment". In the course of this search our discipline will face a number of challenges.

First, we need new analytical tools that take account of the fading of the public-private divide in order to explore the new business-society relationships and the contribution of private actors to public policy. Crane, Matten, and Moon (2008), for example, have recently proposed to build upon insights from discussions in political theory and to regard corporations as political actors that can be held responsible to provide social rights (e.g., some corporations manage health care issues); enabling civil rights (e.g., some corporations protect the freedom of speech of workers and their associations in countries with repressive regimes), and channeling political rights (e.g., some corporations engage in self-regulation). Some corporations behave as "corporate citizens" and assume a state-like role when they administer the rights of citizens and provide public goods to the communities of the host countries in which they operate. Likewise, Scherer and Palazzo (2007) have developed a political conception of CSR and have suggested considering business firms as political actors in public policy processes above and beyond the state.

Second, the political activities of corporations are a potential threat to democratic societies. Therefore, we need to explore new ways of strengthening political communities and making business firms democratically accountable. As Detomasi (2008: 807) maintains, the CSR efforts of corporations "- or their lack thereof - will significantly impact on the external, social and political environment in which they operate." However, corporate managers are neither elected nor democratically controlled and the activities of globally operating business firms are no longer embedded in a democratically defined system of rules, due to the fading of the regulatory power of the state and the outsourcing and off-shoring of business activities to locations beyond the reach of a state's rule of law. As a consequence the public influence of 
state institutions on businesses is in decline, and at the same time the growing political influence of private businesses on national governance and on international organizations threatens the democratic self-determination of political communities. This is even more the case when the political activities of business firms are reduced to strategic lobbying so as to make instrumental use of the political system in favor of the profit motives of the firms while neglecting the concerns of the communities and the natural environments in which the business firms are operating. Thus the strategic intrusion of corporate interests into national governance is undermining the regulatory capability of the state system in the post-national constellation even further and is weakening democracy. As Robert Dahl (1998: 73) reminds us:

"To govern a state ... requires incorruptibility, a firm resistance to all the enormous temptations of power, a continuing and inflexible dedication to the public good rather than benefits for oneself or one's group." (emphasis in the original here omitted)

Third, we need to develop a new understanding of politics that extends beyond the narrow conception of power politics common in the management literature. We suggest that an expanded view on corporate politics and the role of business in a global society is necessary to sufficiently address the new political role of business in global governance, and to critically analyze corporate engagement with public policy (Scherer and Palazzo 2007; Crane et al 2008). In contrast to the instrumental view of power politics, alternative conceptions of politics with respect to corporations have to broaden the concept in three ways. (1) A new concept of politics must go beyond the narrow concept of politics-as-profit-seeking-behavior and consider "political" any process in which people collectively regulate their social conditions and decide on the direction they wish to take (Young 2004) regardless of the various motivations the actors have to enter this process. Such an extended concept may be helpful to capture the variety of reasons of why business firms and corporate managers engage in politics (selfinterest, altruism, imitation, duties, virtues, etc.). (2) A broadened concept of politics has to 
emphasize the common good as the final goal of politics (Elster 1986). Such a normative benchmark is needed in order to discuss under what conditions the political behavior of business firms can be socially accepted and when it has to be considered as dangerous for democracy and the well-being of society (Palazzo and Scherer 2006). (3) Rather than conceiving of politics as an aggregation of fixed preferences in a power game (Elster 1986) and thus emphasizing the outcomes of the political process, the new concept emphasizes the role of communication and discourse in the process of forming and transforming preferences (see, e.g., Risse 2000; Müller 2004; Deitelhoff 2009). Therefore, it may be helpful to rather conceive of this political role of business as an engagement in the deliberative process of democratic will formation, as it is discussed in political sciences and theory of democracy (Dryzek 1999; Habermas 1996; Rasche \& Esser, 2006; Scherer and Palazzo 2007).

Fourth, we need to further explore the internal organizational consequences of the political mandate of the business firm. We need to analyze what organizational structures and processes will support or impede the new political role of the corporation (Edward and Willmott 2008). What are the implications of compliance or integrity organizations (Paine 1994; Stansbury and Barry 2007)? Will the new political role be assigned to a designated department or will it be the task of general management? What are the consequences for the human resources function (selection, appraisal, development)? How does the discussion of global governance change the discussion of corporate governance (Thompson 2008)? And what are the implications for leadership style and responsibility (Maak and Pless 2006)? These are only a few of the challenges that need to be addressed in business ethics and management research.

It seems as if a fresh view on the role of business in society must consider theories outside the mainstream. Therefore, we suggest a paradigm shift in research on corporate social responsibility, building upon some main findings in political philosophy (Dryzek 1999; Habermas 1996), political science (international relations) (Risse 2000; Deitelhoff 2009), and legal studies (Parker and Braithwaite 2003) as well as in some unorthodox approaches to CSR 
(for an overview see Scherer and Palazzo 2007). This expansion of perspective will help us to critically reconsider some of the basic assumptions about the role of the corporation in society, and also to develop alternatives to mainstream views of the firm. In view of the widespread practices of politically responsible behavior of business firms on the one hand (Bies et al. 2007; Matten and Crane 2005), and, on the other hand, the slow conceptual response of research in business related fields, this agenda may help business research and practice find its cause again (Walsh et al. 2003).

\section{Acknowledgements}

The guest editors of this Special Issue would like to thank BEQ editor Gary Weaver and our little army of reviewers for their diligent support in making this Special Issue happen. The anonymous reviewers, whose meticulous work we immensely appreciate, included Frank de Bakker, Bobby Banerjee, Pratima Bansal, John Boatright, John Campbell, Ben Cashore, Wesley Cragg, Andrew Crane, Colin Crouch, Richard De George, Jonathan Doh, Tom Donaldson, Tom Dunfee, Peter Edward, Timothy Fort, Jeff Frooman, Mike Geppert, Dirk Ulrich Gilbert, Jerry Goodstein, Virginia Haufler, Joseph Heath, John Hendry, Pursey Heugens, Volker Hoffmann, Bryan Husted, David Kinley, David Levy, Ian Maitland, Alexei Marcoux, Joshua Margolis, Jeremy Moon, Kamal Munir, Richard Nielsen, Wayne Norman, Hans van Oosterhout, Eric Orts, Andreas Rasche, Paul Shrivastava, Diane Swanson, Grahame Thompson, Sandra Waddock, Ben Wempe, Andrew Wicks, Cynthia A. Williams, Hugh Willmott, Duane Windsor, Klaus Dieter Wolf, Donna Wood, and others. They all deserve credit for improving the thinking published in this Special Issue. 


\section{References}

Asongu J. J. 2007. “Coca-Cola's Response to HIV/AIDS in Africa: A Case Study on Strategic Corporate Social Responsibility.” Journal of Business and Public Policy, 1 (1) [www.jbpponline.com/article/viewFile/1023/816].

Aupperle, K. E., A. B. Carroll, and J. D. Hartfield. 1985. “An Empirical Examination of the Relationship Between Corporate Social Responsibility and Profitability." Academy of Management Journal, 28:446-463.

Bales, D. 1999. Disposable People. New Slavery in the Global Economy. Los Angeles, Calif.: University of California Press.

Bales, D. 2005. Understanding Global Slavery. Los Angeles, Calif.: University of California Press.

Banerjee, S. B. 2003. "The Practice of Stakeholder Colonialism: National Interest and Colonial Discourses in the Management of Indigenous Stakeholders.” In Postcolonial Theory and Organizational Analysis, ed. A. Prasad. New York: Palgrave, 255-279

Banerjee, S. B. 2007. Corporate Social Responsibility. The Good, the Bad and the Ugly. Cheltenham, UK: Edward Elgar.

Barley, S. R. 2007. “Corporations, Democracy, and the Public Good.” Journal of Management Inquiry, 16:201-215.

Baron, D. P. 2003. "Private Politics.” Journal of Economics \& Management Strategy, 12:3166.

Barro, R. J. 1994. “Democracy: A Recipe for Growth?” Wall Street Journal (December 1, 1994): A18.

Baumol, W. J., and S. A. B. Blackman. 1991. Perfect Markets and Easy Virtue: Business Ethics and the Invisible Hand. Cambridge, Mass.: Blackwell.

Beaver W. R. 2005. "Battling Wal-Mart: How Communities Can Respond.” Business and Society Review, 110(2):159-169.

Beck, U. 2000. What is Globalization? Cambridge, UK: Polity Press.

Berman, S. L., A. C. Wicks, S. Kotha, and T. M. Jones. 1999. "Does Stakeholder Orientation matter? The Relationship Between Stakeholder Management Models and Firm Financial Performance." Academy of Management Journal, 42:488-506.

Bernstein, S., and B. Cashore. 2007. "Can Non-state Global Governance be Legitimate? An Analytical Framework." Regulation and Governance 1:1-25. 
Bies, R. J., J. M. Bartunek, T. L. Fort, and M. N. Zald. 2007. “Corporations as Social Change Agents: Individual, Interpersonal, Institutional, and Environmental Dynamics.” Academy of Management Review, 32:788-793.

Boddewyn, J., and T. Brewer. 1994. "International Business Political Behaviour: New Theoretical Directions.” Academy of Management Review, 19:119-143.

Bonardi J.-P., A. Hillman, and G. Keim. 2005. "The Attractiveness of Political Markets: Implication for Firm Strategies.” Academy of Management Review, 30:397-413.

Braithwaite, J., and P. Drahos. 2000. Global Business Regulation. Cambridge, UK: Cambridge University Press.

Brewer, A. 1980. Marxist Theories of Imperialism: A Critical Survey. London: Routledge.

Carroll, A. B. 1979. “A Three-dimensional Conceptual Model of Corporate Performance.” Academy of Management Review, 4:497-505.

Chandler, A. D., and B. Mazlish., eds. 2005. Leviathans. Multinational Corporations and the New Global History. Cambridge, UK: Cambridge University Press.

Clapham, A. 2006. Human Rights Obligations of Non-state Actors. Oxford: Oxford University Press.

Cohen, R., and P. Kennedy. 2000. Global Sociology. London: Macmillan.

Colley, J. L. Jr., J. L. Doyle, G. W. Logan, and W. Stettinius. 2003. Corporate Governance. New York: McGraw Hill.

Cragg, W., ed. 2005. Ethics Codes, Corporations and the Challenge of Globalization. Cheltenham, UK: Edward Elgar.

Crane, A., and D. Matten. 2005. "Corporate Citizenship: Missing the Point or Missing the Boat? - A Response to van Oosterhout.” Academy of Management Review, 30(3):681684.

Crane, A., D. Matten, and J. Moon. 2008. Corporations and Citizenship. Cambridge: Cambridge University Press.

Dahl, R. A. 1998. On Democracy. London: Yale University Press.

de Bakker, F. G. A. and F. den Hond. 2008. "Introducing the Politics of Stakeholder Influence.” Business \& Society, 47:8-20.

Deitelhoff, N. 2009. “The Discursive Process of Legalization: Charting Islands of Persuasion in the ICC Case.” International Organization, 63:33-65.

den Hond, F. and F. G. A. de Bakker. 2007. "Ideologically Motivated Activism: How Activist Groups Influence Corporate Social Change Activities.” Academy of Management Review, 32:901-924. 
Destler, C. M. 1946. “Entrepreneurial Leadership among the „Robber Barons“: A Trial Balance." The Journal of Economic History, Vol. 6, Supplement: The Tasks of Economic History:28-49.

Detomasi, D. A. 2008. "The Political Roots of Corporate Social Responsibility." Journal of Business Ethics, 82:807-819.

Dubbink, W. 2004. “The Fragile Structure of Free-market Society.” Business Ethics Quarterly, 14:23-46.

Dryzek, J. S. 1999. “Transnational Democracy.” Journal of Political Philosophy, 7 (1):30-51.

Dunfee, T. W., and T. L. Fort. 2003. "Corporate Hypergoals, Sustainable Peace, and the Adapted Firm." Vanderbilt Journal of Transnational Law, 36:563-617.

Edward, P., and H. Willmott 2008. "Structures, Identities and Politics: Bringing Corporate Citizenship into the Corporation." In Handbook of Research on Global Corporate Citizenship, eds. Scherer, A. G., and G. Palazzo. Cheltenham: Edward Elgar, 405-429.

Elster, J. 1986. "The Market and the Forum: Three Varieties of Political Theory." In Foundations of Social Choice Theory, eds. J. Elster and A. Hylland. Cambridge, UK: Cambridge University Press, 103-132

Fort, T. L., and C. A. Schipani. 2004. The Role of Business in Fostering Peaceful Societies. Cambridge, UK: Cambridge University Press.

Frederick, W. C. 1998. "Business and Society.” In The Concise Blackwell Encyclopaedia of Management, eds. Cooper, G. L., and C. Argyris. Oxford, UK: Blackwell, 54-56.

Friedman, M. 1962. Capitalism and Freedom. Chicago: University of Chicago Press.

Friedman, M. 1970. "The Social Responsibility of Business is to Increase its Profit.” The New York Times Magazine, 13 September. Reprint in Ethical Issues in Business: A Philosophical Approach, eds. Donaldson, T., and P. H. Werhane. Englewood Cliffs, N.J.: Prentice Hall, 217-223.

Giddens, A. 1990. Consequences of Modernity. Cambridge, UK: Polity Press.

Gilbert, D. U., and A. Rasche. 2007: "Discourse Ethics and Social Accountability - The Ethics of SA 8000.” Business Ethics Quarterly, 17:187-216.

Gond, J.-P., Palazzo, G., and K. Basu. 2009. "Reconsidering Instrumental Corporate Social Responsibility Through the Mafia Metaphor.” Business Ethics Quarterly, 19:57-85.

Guidolin, M., and E. La Ferrara. 2007. "Diamonds are Forever, Wars are Not: Is Conflict Bad for Private Firms?” American Economic Review, 97:1978-1993.

Habermas, J. 1996. Between Facts and Norms: Contributions to a Discourse Theory of Law and Democracy. Cambridge, Mass.: MIT Press. 
Habermas, J. 2001. The Postnational Constellation. Cambridge, Mass.: MIT Press.

Henderson, P. D. 2001. Misguided Virtue: False Notions of Corporate Social Responsibility. London: Institute of Economic Affairs.

Hess, D., N. Rogovsky, and T. W. Dunfee. 2002. “The Next Wave of Corporate Community Involvement." California Management Review, 44 (2):110-125.

Hightower, J. 2002. "How Wal Mart is Remaking our World." http://www.alternet.org/story/12962/

Hill, R. P., D. Stephens, and I. Smith. 2003. "Corporate Social Responsibility: An Examination of Individual Firm Behaviour.” Business and Society Review, 108:339-364.

Hillman, A. J., G. D. Keim, and D. Schuler. 2004. “Corporate Political Activity: A Review and Research Agenda.” Journal of Management, 30:837-857.

Hsieh, N. 2009. "Does Global Business Have a Responsibility to Promote Just Institutions?" Business Ethics Quarterly, 19:251-273.

Irwin, D. A. 2002. Free Trade under Fire. Princeton, Princeton University Press.

Jensen, M. C. 2002. "Value Maximization, Stakeholder Theory, and the Corporate Objective Function.” Business Ethics Quarterly, 12:235-256.

Josephson, M. 1934. The Robber Barons. The Great American Capitalists, 1861-1901. New York: Harcourt, Brace and Company.

Kaul, I., P. Conceição, K. Le Goulven, and R. U. Mendoza, eds. 2003. Providing Global Public Goods. Oxford: Oxford University Press.

Klein, J. G., N. C. Smith, and A. John. 2004. "Why we Boycott: Consumer Motivations for Boycott Participation.” Journal of Marketing 68:92-109.

Klein, N.: 2000. No Logo. New York: Picador.

Kobrin, S. J. 2001. “Sovereignity@bay: Globalization, Multinational Enterprise, and the International Political System.” In The Oxford Handbook of International Business, eds.

A. M. Rugman and T. L. Brewer. New York: Oxford University Press, 181-205.

Korten, D. C. 2001. When Corporations Rule the World. $2^{\text {nd }}$ ed. San Fransisco: BerretKoehler.

Krauss, M. 1997. How Nations Grow Rich. New York: Oxford University Press.

Laufer, W. S. 2003. "Social Accountability and Corporate Greenwashing." Journal of Business Ethics, 43: 253-261.

Leisinger, K. M. 2009. “Corporate Responsibilities for Access to Medicines.” Journal of Business Ethics, 85: 3-23. 
Maak, T., and N. M. Pless. 2006. "Responsible Leadership in a Stakeholder Society." Journal of Business Ethics, 66:99-115.

Mandel, E. 1999. Late Capitalism. $2^{\text {nd }}$ ed. London: Verso.

Margolis, J. D., and Walsh, J. P. 2003. "Misery Loves Companies: Rethinking Social Initiatives by Business.” Administrative Science Quarterly, 48:268-305.

Martinez-Mont, L. 1996. “Sweatshops are Better Than no Shops.” Wall Street Journal, June 25.

Mathews, J. T. 1997. "Power Shift.” Foreign Affairs, January/February: 50-66.

Matten, D., and A. Crane. 2005. "Corporate Citizenship: Towards an Extended Theoretical Conceptualization.” Academy of Management Review, 30:166-179.

Mokhiber, R., and R. Weissman 1999. Corporate Predators: The Hunt for Mega-profits and the Attack on Democracy. Common Courage Press.

Müller, H. 2004. "Arguing, Bargaining and all that: Communicative Action, Rationalist Theory and the Logic of Appropriateness in International Relations." European Journal of International Relations, 10: 395-435.

Norberg, J. 2003. In Defence of Global Capitalism. Cato Institute.

Norman, W., and P.-Y. Néron. 2008. "Citizenship Inc. - Do We Really Want Businesses to be Good Corporate Citizens?" Business Ethics Quarterly, 18(1):1-26.

Norton, M.B., D. M. Katzman, P. D. Escott, H. P. Chudacoff, T. G. Paterson, and W. M. Tuttle Jr. 1986. “A People and a Nation: A History of the United States.” Boston: Houghton Mifflin Company.

Okie, S. 2006. "Fighting HIV. Lessons from Brazil." The New England Journal of Medicine, 354 (19):1977-1981.

Paine, L. S. 1994. "Managing for Organizational Integrity.” Harvard Business Review, 72:106-117.

Palan, R. 2003 The Offshore World. Sovereign Markets, Virtual Places, and Nomad Millionaires. Ithaca, N.Y.: Cornell University Press.

Palazzo, G., and A. G. Scherer. 2006. "Corporate Legitimacy as Deliberation. A Communicative Framework." Journal of Business Ethics, 66:71-88.

Palazzo, G., and A. G. Scherer. 2008. “Corporate Social Responsibility, Democracy, and the Politicization of the Corporation.” Academy of Management Review, 33: 773-775.

Parker, C., and J. Braithwaite. 2003. "Regulation.” In The Oxford Handbook of Legal Studies, eds. Cane, P., and M. Tushnet. Oxford, UK: Oxford University Press, 119-145. 
Perrow, C. 2002. Organizing America: Wealth, Power and the Origins of Corporate Capitalism. Princeton, NJ: Princeton University Press.

Porter, M. E., and M. C. Kramer 2002. "The Competitive Advantage of Corporate Philanthropy." Harvard Business Review, 80 (12):57-68.

Rasche, A. and D. E. Esser. 2006. "From Stakeholder Management to Stakeholder Accountability. Applying Habermasian Discourse Ethics to Accountability Research.” Journal of Business Ethics, 65:251-267.

Rawlinson, P. 2002. "Capitalists, Criminals and Oligarchs: Sutherland and the New "Robber Barons"." Crime, Law \& Social Change, 37:293-307.

Reich, R. B. 2007. Supercapitalism: The Transformation of Business, Democracy and Everyday Life. New York: Alfred A. Knopf.

Reinicke, W. H. and F. Deng, with J. M. Witte, T. Benner, B. Whitaker, and J. Gershman. 2000. Critical Choices: The United Nations, Networks, and the Future of Global Governance. Ottawa: International Development Research Centre.

Risse, T. 2000. ““'Let’s argue!”: Communicative Action in World Politics.” International Organization, 54:1-39.

Roberts, J. 2003. “The Manufacture of Corporate Social Responsibility: Constructing Corporate Sensibility." Organization, 10:249-265.

Saviano, R. 2008. Gomorra. Italy’s Other Mafia. New York: Macmillan.

Scherer, A. G., and G. Palazzo. 2007. "Toward a Political Conception of Corporate Responsibility. Business and Society Seen From a Habermasian Perspective." Academy of Management Review, 32: 1096-1120.

Scherer, A.G., and G. Palazzo. 2008a. "Globalization and Corporate Social Responsibility.” In The Oxford Handbook of Corporate Social Responsibility, eds. Crane, A., A. McWilliams, D. Matten, J. Moon and D. Siegel.Oxford: Oxford University Press: 413-431.

Scherer, A. G., and G. Palazzo, eds. 2008b. Handbook of Research on Global Corporate Citizenship. Cheltenham, UK: Edward Elgar.

Scherer, A. G., G. Palazzo, and D. Baumann. 2006. "Global Rules and Private Actors. Towards a New Role of the TNC in Global Governance.” Business Ethics Quarterly, 16: $502-532$.

Scherer, A. G., and M. Smid. 2000. "The Downward Spiral and the U.S. Model Principles. Why MNEs Should Take Responsibility for the Improvement of World-wide Social and Environmental Conditions." Management International Review, 40:351-371. 
Scholte, J. A. 2005. Globalization: A Critical Introduction. $2^{\text {nd }}$ edition. New York: Palgrave. Schuler, D.A., and K. Rehbein. 1995. "Pursuing Strategic Advantage Through Political Means: A Multivariate Approach.” Academy of Management Journal, 45:659-672.

Shaffer, B. 1995. "Firm-level Responses to Government Regulation: Theoretical and Research Approaches.” Journal of Management, 21:495-514.

Shell, G. R. 2004. Make the Rules or Your Rivals Will. New York: Crown Business.

Spar, D. L., and L. T. La Mure. 2003. "The Power of Activism: Assessing the Impact of NGOs on Global Business." California Management Review, 45:78-101.

Stansbury, J., and B. Barry. 2007. "Ethics Programs and the Paradox of Control." Business Ethics Quarterly, 17:239-261.

Strand, R. 1983. “A Systems Paradigm of Organizational Adaptations to the Social Environment." Academy of Management Review, 8:90-96.

Suchman, M. C.: 1995. _Managing Legitimacy: Strategic and Institutional Approaches." Academy of Management Review, 20:571-610.

Sundaram, A. K., and A. C. Inkpen. 2004. "The Corporate Objective Revisited.” Organization Science, 15:350-363.

Swanson, D. L. 1999. “Toward an Integrative Theory of Business and Society: A Research Strategy for Corporate Social Performance.” Academy of Management Review, 24:506-521.

Taylor, K. M. 2004. “Thicker Than Blood: Holding Exxon Mobil Liable for Human Rights Violations Committed Abroad.” Syracuse Journal of International Law and Commerce, 31(2):274-297.

Thompson, G. F. 2008. “The Interrelationship between Global and Corporate Governance: Towards a Democratization of the Business Firm?" In Handbook of Research on Global Corporate Citizenship, eds. Scherer, A. G., and G. Palazzo. Cheltenham: Edward Elgar, 476-498.

Valente, M., and A. Crane 2009. "Private, but Public. Companies in Emerging Markets Often have to Take on Services Usually Provided by the Government. It isn't Always Easy." The Wall Street Journal, March 23: R6.

van Oosterhout, J. 2005. “Corporate Citizenship: An Idea Whose Time has not yet Come." Academy of Management Review, 30(4):677-684.

van Oosterhout, J. 2008. "Transcending the Confines of Economic and Political Organization?" Business Ethics Quarterly, 18(1):35-42. 
Walsh, J. P. 2005. “Book Review Essay: Taking Stock of Stakeholder Management.” Academy of Management Review, 30:426-452.

Walsh, J. P., Weber, K., and Margolis, J. D. 2003. "Social Issues and Management: Our Lost Cause Found.” Journal of Management, 29:859-881.

Warren, B. 1980. Imperialism: Pioneer of Capitalism. London: Verso.

Wayman, F. W. and P. R. Diehl. 1994. Reconstructing Realpolitik. An Empirically Based Critique of Realism. University of Michigan Press.

Were, M. 2003. "Implementing Corporate Responsibility - The Chiquita Case.” Journal of Business Ethics, 44:247-260.

Wolf, K. D. 2008. "Emerging Patters of Global Governance: The New Interplay Between the State, Business and Civil Society.” In Handbook of Research on Global Corporate Citizenship, eds. Scherer, A. G., and G. Palazzo. Cheltenham: Edward Elgar, 225-248.

Young, I. M. 2004. "Responsibility and Global Labor Justice.” The Journal of Political Philosophy, 12:365-388.

Zadek, S. 2004. "The Path to Corporate Responsibility.” Harvard Business Review, 82:125132.

\section{Short biographies}

Andreas Georg Scherer is professor of business administration and theories of the fi $\mathrm{rm}$. He is director of the Institute of Organization and Administrative Science (IOU) and holds a chair at the University of Zurich (Switzerland). He has earned his doctorate in strategic management (1994) and his doctoral habilitation degree (2000) in international management, both at the University of Erlangen-Nuremberg (Germany). From 2000-2002 he was professor of management and public administration at the University of Constance (Germany). His research interests are in business ethics, critical theory, international management, organization theory, and philosophy of science. He has published nine books, most recently the Handbook of Research on Global Corporate Citizenship (co-edited with G. Palazzo). His work has appeared in Academy of Management Review, Business Ethics Quarterly, Journal of Business Ethics, 
Management International Review, Organization, Organization Studies, and in numerous volumes and other journals. He is associate editor of Business Ethics Quarterly and is a member of the editorial boards of Business and Society, Business Research, Organization, and Organization Studies. E-mail: andreas.scherer@iou.uzh.ch

Guido Palazzo is professor of business ethics at the University of Lausanne (Switzerland). He graduated in business administration at the University of Bamberg (Germany) and earned his $\mathrm{PhD}$ in political philosophy (1999) from the University of Marburg (Germany). His research interests are in corporate social responsibility, corporate branding, democratic theory, and organizational ethics. He is associate editor of Business Ethics Quarterly and member of the editorial boards of Academy of Management Review and Business \& Society. His work has appeared in journals such as Academy of Management Review, Business Ethics Quarterly, and Journal of Business Ethics. Email: guido.palazzo@unil.ch

Dirk Matten holds the Hewlett-Packard Chair in Corporate Social Responsibility and is professor of strategy at the Schulich School of Business, York University, Toronto. His doctoral degree and his habilitation are from Heinrich-Heine-University Düsseldorf in Germany. Dirk has taught and done research at academic institutions in Australia, Belgium, Britain, Canada, the Czech Republic, France, Germany, Italy, and the US. His work has appeared in journals such as Academy of Management Review, Journal of Management Studies, Organization Studies, British Journal of Management, and The Geneva Papers. Among his recent books count the Oxford Handbook of Corporate Social Responsibility (Oxford University Press 2008, co-editor) and Corporations and Citizenship (Cambridge University Press 2008, coauthor).E-mail: DMatten@schulich.yorku.ca 